
\title{
SM̂PP
}

Migration Studies - Review of Polish Diaspora nr 2 (176)/2020, http://www.ejournals.eu/Studia-Migracyjne/ DOI: 10.4467/25444972SMPP.20.019.12335

\section{Sprawy polskie w Kanadzie w czasie I wojny światowej}

\author{
ANNA RECZYŃSKA 1 \\ ORCID: 0000-0002-8340-7433 \\ Uniwersytet Jagielloński
}

Artykuł przedstawia kilka przykładów obrazujących oddziaływanie wydarzeń I wojny światowej na żyjących w Kanadzie polskich imigrantów, pozycję polskiej grupy etnicznej w tym kraju oraz na aktywność osób polskiego pochodzenia na rzecz rekrutacji do wojska polskiego w Ameryce Północnej. Polaków, którzy byli poddanymi Niemiec lub monarchii austro-wegierskiej traktowano jak przedstawicieli państw wrogich. Mieli obowiązek rejestracji i regularnego zgłaszania się na policję a niektórzy zostali internowani w stworzonych w czasie wojny obozach pracy. Część z nich była z tych obozów zwolniona po interwencji polskich organizacji i polskich duchownych. Żołnierze polskiego pochodzenia, zarówno ochotnicy jak i poborowi, znaleźli się także w oddziałach Kanadyjskich Sił Ekspedycyjnych walczących w Europie. Ponad 20 tys. polskich ochotników z USA (w tym ponad 200 z Kanady) zgłosiło się też do obozu szkoleniowego utworzonego w Niagara-on-the-Lake, Ontario, przy granicy z USA. Problemy z organizacją i funkcjonowaniem tego obozu oraz opinie o polskich ochotnikach, kształtowały nastawienie wielu Kanadyjczyków do polskiej grupy etnicznej i nowotworzonego Państwa Polskiego.

Słowa kluczowe: I wojna światowa, diaspora polska w Kanadzie, Niagara-on-the-Lake camp, Armia Hallera, pułkownik Arthur D’Orr LePan

\section{Polish Issues in Canada During World War I}

The article presents the impact of World War I on Polish immigrants in Canada, the position of the Polish ethnic group in this country and the efforts of persons of Polish descent in regard to recruitment for the Polish Army in North America. Poles, who were subjects of Germany or the AustroHungarian Empire were treated as enemy aliens. Those people were forced to register and report to the police on a regular basis and some of them were interned in labour camps during the war. Some were released from the camps after an intervention of Polish organizations and priests. Soldiers of

1 Kontakt: anna.reczynska@uj.edu.pl 
Polish descent, volunteers and recruits also fought in the Canadian Expeditionary Forces in Europe. Over 20,000 Polish volunteers from the US (including over 200 from Canada) enrolled in a training camp formed in Niagara-on-the-Lake, Ontario on the border with the US. The problems with the organization and functioning of the camp, and opinions on Polish volunteers shaped the attitude of many Canadians towards the Polish diaspora and the newly established Polish state.

Keywords: World War I, Polish Diaspora in Canada, Niagara-on-the-Lake camp, Haller's Army, Colonel Arthur D’Orr LePan

Polskie opracowania historyczne i podręczniki poświęcone tematyce I wojny światowej niezwykle rzadko wymieniają Kanadę wśród krajów koalicji walczącej z państwami centralnymi. Nie ma w nich ani informacji o roli odegranej przez żołnierzy kanadyjskich w walkach toczonych we Francji ani o wewnętrznych i zewnętrznych komplikacjach wojennej polityki kanadyjskiej. W publikacjach na temat Armii Polskiej we Francji (nazywanej Armią Hallera i Armią Błękitną) zwykle pojawiają się jedynie wzmianki o tym, że trzon tej jednostki stanowili ochotnicy z USA oraz że szkolono ich w obozie na terenie Kanady. Zupełnie pomijany jest w nich jednak kontekst kanadyjski². Wycinkowe dokumenty i nie zawsze spójne komentarze na temat aktywności polskich imigrantów na terenie Kanady w okresie I wojny światowej można znaleźć w poświęconej Armii Hallera książce Wacława Gąsiorowskiego o3 oraz w publikacjach dokumentacyjnych, bazujących na tej pracy, wydanych w 1957 r. w USA i w 2018 r. w Polsce ${ }^{4}$. Ciekawe materiały oraz opis rekrutacji do Armii Błękitnej zawierają natomiast najnowsze prace Anitty Maksymowicz ${ }^{5}$, ale autorka koncentruje się na aktywności Polonii amerykańskiej. Najpełniej dzieje polskiego obozu w Niagara-on-the-Lake zostały opisane w książce poświęconej historii kanadyjskiego wojskowego obozu ćwiczebnego funkcjonującego w tej miejscowości. Ta bogato ilustrowana publikacja kanadyjska skupia się jednak na historii lokalnej, nie przedstawiając szerszego kontekstu ani kanadyjskiego, ani polskiego'.

Warto więc przypomnieć, że Kanada, będąca od 1867 r. autonomiczną kolonią brytyjską, znalazła się w wojnie automatycznie już 4 sierpnia 1914 r., gdy Wielka

2 Zob. Generał Józef Haller i jego żołnierze. Informator wystawy Muzeum Niepodległości, red. T. Skoczek, Warszawa-Wrocław 2018; D. Radziwiłowicz, Błękitna Armia w 80. rocznicę utworzenia, Warszawa 1997; skrótowo o polskim obozie zob.: J. Auleytner, Komunikacja pocztowa w Błękitnej Armii Hallera w latach 1917-1920, Warszawa 2017, s. 42-44 i 56.

3 W. Gąsiorowski, Historia Armii Polskiej we Francji 1915-1916, Łódź 1939.

${ }^{4}$ Obie pozycje w znacznej części powtarzają teksty zamieszczone przez Gąsiorowskiego, wprowadzając pewne uzupełnienia, ale też skróty. Zob. Czyn zbrojny wychodźstwa Polskiego w Ameryce. Zbiór dokumentów i materiałów historycznych, New York-Chicago 1957; Czyn zbrojny wychodźstwa Polskiego w Ameryce 1914-1920. Zbiór dokumentów i materiałów historycznych, red. J. Walter, New York-Opole 2018 [dalej: Czyn zbrojny wychodźstwa, ... red. J. Walter.]

${ }^{5}$ A. Maksymowicz, Agnieszka Wisła i działalność Polek w Ameryce na rzecz ochotników weteranów Btękitnej Armii, Nowy Jork-Opole 2015; A. Maksymowicz, W drodze do niepodległości. Kanadyjski przystanek Obóz Kościuszko w Niagara-on-the Lake (1917-1919), Zielona Góra 2017.

${ }^{6}$ R. Merritt, Training for Armageddon. Niagara Camp in the Great War, 1914-1919, Victoria BC 2015. 


\section{SM̂PP}

Brytania wypowiedziała Niemcom wojnę. W okresie od 1914 do 1918 kraj ten, liczący wówczas około 8 milionów mieszkańców, wysłał do Europy 625000 żołnierzy i ponad trzy tysiące pielęgniarek. Kanadyjczycy wyróżnili się w walkach pod Ypres i nad Sommą, a w kwietniu 1917 r. w rejonie Vimy Ridge ${ }^{7}$. W ostatniej z wymienionych bitew, mimo ogromnych strat, odnieśli zwycięstwo i do dziś Vimy Ridge jest dla Kanadyjczyków symbolem ich udziału w I wojnie. Jej bilans był dla kanadyjskich żołnierzy tragiczny: 60 tys. z nich (czyli 10\% Canadian Expeditionary Forces) zginęło, a 172 tys. zostało rannych. Wojna przyniosła też wiele zmian w kanadyjskiej gospodarce. Załamanie eksportu zboża skutkowało bezrobociem w regionach rolniczych, a przestawienie przemysłu na kredytowaną przez państwo produkcję dla wojska doprowadziło do ograniczenia praw pracowników i do wysokiej inflacji ${ }^{8}$.

Wojenna histeria, podsycana przez propagandę, nasiliła w Kanadzie napięcia między anglofonami i frankofonami oraz przyczyniła się do powstawania nowych konfliktów w wieloetnicznym społeczeństwie tego kraju. Imigranci niemieccy oraz ich potomkowie, wcześniej uważani za idealnych osadników, byli od początku wojny traktowani jako element niebezpieczny, określany jako enemy aliens. W 1916 r. zmieniono nawet na Kitchener nazwę miasta Berlin, położonego w prowincji Ontario, a założonego przez niemieckich mennonitów na początku XIX w. Do kategorii enemy aliens Kanadyjczycy zaliczali również imigrantów z Austro-Węgier. Wcześniej przeważnie nie dostrzegali wśród nich różnic etnicznych i zbiorowo nazywali ich Galicjanami. W okresie wojny kwestionowano lojalność całej tej zbiorowości. Społeczność ukraińska sama dostarczyła argumentów do podejrzeń. 27 lipca 1914 r. - na kilka dni przed wybuchem wojny - Nikita Budka, greckokatolicki biskup aspirujący do roli duchowego przywódcy znacznej części żyjących w Kanadzie Ukraińców, skierował do swych wiernych list pasterski. Wezwał w nim imigrantów, którzy byli austriackimi rezerwistami, do powrotu do Galicji i obrony ziemi ojczystej przed Rosjanami. Biskup nie przewidział, że wkrótce Imperium Brytyjskie (w tym również Kanada) zostanie wojennym sojusznikiem Rosji. 6 sierpnia Budka wydał kolejny list, w którym tłumaczył wiernym zmianę sytuacji. Podkreślał w nim z naciskiem konieczność wypełnienia przez imigrantów obowiązków w stosunku do kraju zamieszkania, czyli Kanady i wspierania jej wysiłków wojennych. Przeciwnicy biskupa, głównie nastawieni antyklerykalnie młodzi Ukraińcy, zdążyli już jednak nagłośnić pierwszy list. Władze kanadyjskie wykorzystały zawarte w nim stwierdzenia do kwestionowania lojalności hierarchy, jego współwyznawców oraz całej społeczności ukraińskiej. Zaważyło to

7 Na pomniku Vimy Rige, upamiętniającym kanadyjskich żołnierzy poległych $w$ tej krwawej bitwie w kwietniu 1917 r., a także innych Kanadyjczyków, którzy zginęli we Francji w czasie I wojny światowej, można znaleźć także polskie nazwiska.

8 J.M. Bumsted, The Peoples of Canada. A Post-Confederation History, Oxford-New York 2004, s. $190-201$.

${ }^{9}$ S. Hryniuk, Pionier Bishop, Pionier Times: Nikita Budka in Canada, Prophets, Priests, and Prodigals. Readings in Canadian Religious History, 1608 to the Present, red. M.G. McGowan, D.B. Marchal, Toronto 1992, s. 157-158. 
na losie wielu ukraińskich imigrantów, którzy nie posiadali prawa stałego pobytu, a o taki status (domicile) przybysze mogli się starać dopiero po 3 latach zamieszkania i pracy w Kanadzie.

W sierpniu 1914 r. parlament kanadyjski przyjął specjalne regulacje na okres wojny (The War Measures Act). Na ich podstawie osoby bez prawa stałego pobytu, a pochodzące z państw toczących wojnę z aliantami, zostały zobowiązane do regularnego zgłaszania się na policję. Rygorem tym objęto około 80 tys. osób. Kilka tysięcy z nich, uznanych za najbardziej niebezpiecznych, internowano i skierowano do obozów pracy. 24 takie obozy utworzono w rejonach odległych od osiedli, wiele z nich w zachodniej Kanadzie. Mieszkańcy tych obozów żyli w bardzo trudnych warunkach i pracowali za minimalne wynagrodzenie, głównie przy wyrębie lasów i budowie dróg. W latach 1916-1917, na 8579 internowanych, było aż 5964 poddanych Austro-Węgier, w tym około 5 tys. Ukraińców ${ }^{10}$. Większość żyjących w Kanadzie polskich imigrantów pochodziła z Galicji i zaboru pruskiego. Podejrzliwość Kanadyjczyków zwracała się więc także w ich stronę. Jan Samulski, mieszkający w Cobalt, Ont., aktywista "Gniazda" (drużyny) polskiego towarzystwa gimnastycznego "Sokół”, tak opisał w pamiętniku nastawienie swych sąsiadów: „Jak się wojna zaczyła, to ludność miastowa uważała nas jako wrogów, bośmy prawie wszyscy byli z Poznańskiego, a to wtenczas należało do zaboru niemieckiego. Tak nas wtenczas uważali jako Niemców. Ludzie innych narodowości myśleli, że my się ćwiczymy, aby w razie gdyby się sposobność nadarzyła, Niemcóm pomóc $w$ ty wojnie..."11

Polaków było w Kanadzie mniej niż Ukraińców i - mimo braku potwierdzonych danych - wiadomo, że relatywnie niewielu Polaków zostało internowanych. Dodatkowo znaczną ich część zwolniono za dobre sprawowanie lub w wyniku poręczeń katolickich duchownych. Warto też odnotować, że interwencje w tej sprawie podejmował Ignacy Jan Paderewski oraz Związek Narodowy Polski z USA. Polskojęzyczna prasa podała, że Kazimierz Żychliński - prezes ZNP oraz adwokat Franciszek Świetlik, udali się w 1916 r. do Ottawy, gdzie od władz otrzymali list polecający upoważniający do odwiedzenia obozów dla internowanych. Dokument ten zawierał też zgodę na wypuszczenie przebywających tam Polaków pod warunkiem poręczenia ze strony adwokata Świetlika oraz złożenia przez osadzonych deklaracji o pozostaniu w Kanadzie i zachowaniu lojalności w stosunku do Wielkiej Brytanii. Procedurą tą objęto około 100 osób ${ }^{12}$. Sprawozdanie Żychlińskiego i Świetlika, zamieszczone W "Dzienniku Związkowym", zawiera też informację, że 16 Polaków przebywających w obozie

10 Internment, w: Historica Canada, http://www.thecanadianencyclopedia.ca/en/article/internment (dostęp 5.01.2020); M. Shykula, B. Korchinski, Pionier Bishop: The Story of Bishop Nicetas Budka's Fifteen Years in Canada, Regina 1991, s. 58-60.

11 J. Samulski, Pamiętnik emigranta polskiego w Kanadzie, red. B. Szydłowska-Ceglowa, Wrocław 1978 , s. 88.

12 Internowani Polacy w Kanadzie wypuszczeni na wolność, "Czas” 30.08.1916, s. 2. 


\section{SM̂PP}

McPhirson, Ontario odmówiło podpisania deklaracji uwolnienia z obawy o los rodzin pozostawionych w Europie ${ }^{13}$.

Polscy imigranci napływali na ziemie kanadyjskie od połowy XIX w., ale w latach bezpośrednio poprzedzających wojnę ruch ten znacznie się nasilił. Badacze szacują, że przed I wojną w Dominium Kanady mieszkało około 100 tys. Polaków i osób polskiego pochodzenia ${ }^{14}$. Większość z nich żyła w rozproszeniu na preriach, ale powstawały też polskie skupiska w miastach i ośrodkach przemysłowych; największe w Winnipeg w prowincji Manitoba. Jeszcze przed wojną istniały tam polskie parafie (dwie rzymskokatolickie i jedna narodowa) oraz kilka organizacji, z których jedne funkcjonowały przy parafiach, a inne niezależnie od nich. Prowadzono działalność samopomocową, oświatową i ubezpieczeniową. Dużą popularnością cieszyło się też "Gniazdo" polskich "Sokołów". Od 1908 r. polscy zakonnicy ze zgromadzenia oblatów wydawali w Winnipeg tygodnik "Gazeta Katolicka", a od 1915 r. wychodził tam także drugi tygodnik o tytule "Czas". Pismo to samo określało się jako ludowe, narodowe, demokratyczne i świeckie. Utrzymywało ono dystans do Kościoła katolickiego, a czasem krytykowało duchowieństwo. Skutkowało to napięciami między obydwiema redakcjami i wzajemnymi atakami na łamach obu pism. Drukowane polemiki często obejmowały również inne sfery, odzwierciedlając podziały i różnice poglądów, a do pewnego stopnia także wojennych orientacji istniejących wewnątrz polskiej społeczności.

Obydwa polskojęzyczne pisma zamieszczały wiele informacji o przebiegu działań wojennych w Europe. "Gazeta Katolicka” - być może pod wpływem problemów, które mieli w Kanadzie Ukraińcy - wyraźnie podkreślała konieczność zachowania lojalności w stosunku do kraju zamieszkania. Dobrym przykładem jest artykuł zamieszczony na łamach tego pisma 12 sierpnia 1914 roku:

Wojna. Zagrały wojenne surmy w starym kraju. Europa stanęła wobec wypadków, które uczynić mogą zupełny przewrót [...]. Co tu na wychodźstwie czynić wypada? [...] nic żadnemu z zaborców do zawdzięczenia nie mamy i nierozsądnem byłoby wracać dla jego obrony. Jako Polacy mamy jeden święty obowiązek - Wyzwolenie Ojczyzny. Jesteśmy dalej na ziemi angielskiej, przyjęliśmy obywatelstwo tutejsze przysięgając na wierność temu krajowi. Nasz cel to Polska wolna i niepodległa, dalej Anglia, w obronie której jako jej obywatele stanąć winniśmy i staniemy, gdy zajdzie potrzeba [...]. Nam trzeba być gotowymi'5.

Warto zwrócić uwagę na fakt, że deklaracje lojalności zamieszczone w cytowanym tekście odwoływały się do angielskiej metropolii, a nie do Dominium Kanady.

13 Wymiar humorystyczny, pokazujący skutki braku znajomości kanadyjskiej historii, ma zamieszczona w publikacji z 2018 r. interpretacja notatki o misji Żychlińskiego i Świetlika. „Dziennik Związkowy”, wydawany w Chicago, nazwał istniejące w Kanadzie obozy jenieckimi, a redaktor zbioru, w którym sto lat później przedrukowano tę gazetową informację, poprzedził ją komentarzem, że chodziło o Polaków jeńców: „którzy w czasie wojny zrekrutowani przymusowo przez zaborcze Niemcy i Austrię, znaleźli się w niewoli na terenie Kanady". Zob.: Czyn zbrojny wychodźstwa..., red. J. Walter, s. 169.

${ }_{14}$ A. Reczyńska, Emigracja z Polski do Kanady w okresie międzywojennym, Wrocław 1986, s. 36.

15 "Gazeta Katolicka”, 12.08.1914, s. 1. 
Dwukrotnie powtórzona też została idea niepodległości Polski. Redakcja gazety wyraźnie starała się jednak dystansować od wielkiej polityki.

W czerwcu 1915 r. w Winnipeg powstał Kanadyjski Komitet Polskiego Funduszu Pomocowego (Canadian Committee for the Polish Relief Fund). W jego władzach znalazło się kilka ważnych i wpływowych postaci z Manitoby, wśród nich premier tej prowincji oraz biskupi katolicki i anglikański. „Gazeta Katolicka” opublikowała informację o tym oraz zapewnienie o modlitwie za dobroczyńców. Przedrukowała też petycję wyrażającą wdzięczność gubernatorowi Manitoby za utworzenie komitetu. Dokument przypominał również o wkładzie pracy polskich robotników w rozwój ekonomiczny Kanady i zawierał prośbę o użycie wpływów: „aby przynajmniej władze rządowe robiły słuszną różnicę pomiędzy Polakami, Niemcami i Austriakami"16. O dalszej działalności Komitetu niestety niewiele wiadomo. Znacznie więcej uwagi niż "Gazeta Katolicka" poświęcał sprawom związanym z wojną polskojęzyczny tygodnik "Czas". Stronę tytułową tej gazety zawsze wypełniały opisy bieżących wydarzeń, decyzji i zmian politycznych oraz odnoszące się do nich komentarze. Na drugiej stronie drukowany był cotygodniowy przegląd operacji wojskowych na wszystkich frontach, a kolejne strony wypełniały relacje z ziem polskich opatrzone nagłówkiem Wieści z Ojczyzny. Opowiadano w nich o uchodźcach, zniszczeniach, braku żywności i problemach życia w warunkach wojennych. Źródeł tych wiadomości nie podawano, ale były to najprawdopodobniej przedruki lub teksty pisane na podstawie prasy polskiej, docierającej do Winnipeg zwykle z kilkutygodniowym opóźnieniem. Czasem redaktor powoływał się na korespondencje A. Czarneckiego, przedstawianego jako specjalny wysłannik kanadyjskiej gazety „Daily News”. „Czas” zamieszczał też informacje o aktywności lokalnej polskiej społeczności, o Komitecie Polek organizującym herbatki, festyny i przedstawienia, z których dochód - za pośrednictwem kanadyjskiego komitetu pomocowego ofiarom wojny na ziemiach polskich oraz Bank of Montreal przekazywano Komitetowi Veveyskiemu, działającemu pod kierownictwem Henryka Sienkiewicza w Szwajcarii. Latem 1916 r. „Czas” wydrukował informację, że Komitet Veveyski potwierdził odbiór sumy 12559 franków z Kanady. Redakcja dodała jednak komentarz, że datki zebrano gównie wśród Kanadyjczyków, a wkład Polaków był niewielki. Wzywano więc rodaków do większej ofiarności na rzecz głodujących współbraci" ${ }^{17}$. Zbiórki na pomoc Polakom w Kraju, a później także dla Armii Polskiej organizowanej we Francji, prowadzili też polscy emigranci mieszkający w Montrealu. Komitet Niesienia Pomocy dla Głodnych w Polsce, zorganizowany tam w 1915 r. przez ojca Franciszka Pyznara (proboszcza lokalnej polskiej parafii), miał zebrać 2600 \$, "które przesłano na ręce wielkiego pisarza Henryka Sienkiewicza do Szwajcarii". Do Związku Narodowego Polskiego w Chicago trafiło natomiast 2336 \$ przekazane

16 Odezwa Polaków do Rządu kanadyjskiego w sprawie zatwierdzenia prawego stanowiska Polaków do Dominium, "Gazeta Katolicka” 23.06.1914, s. 1. Petycja została podpisana przez Zarząd Polsko-Katolickich Towarzystw w Kanadzie.

17 Dwa razy daje ten, kto zaraz daje, „Czas” 16.08.1916, s. 4. 


\section{SM̂PP}

przez montrealskie Towarzystwo Synów Polski na pomoc Polakom w Kraju i Armii gen. Hallera ${ }^{18}$. Brakuje niestety informacji czy Polacy kupowali obligacje kanadyjskiej pożyczki wojennej, którą winnipeski „Czas” reklamował jako korzystną lokatę oszczędności oraz obowiązek względem przybranej ojczyzny ${ }^{19}$.

Jeszcze w roku 1916 „Czas” jednoznacznie odcinał się od militarnego zaangażowania Polaków po stronie rosyjskiej, a Rosjan nazywał Moskalami. Redakcyjne komentarze krytycznie odnosiły się też do podziałów występujących wśród Polaków, do orientacji „prusofilskich i moskalofilskich” oraz „do marzeń, że z przelanej krwi wyrośnie Polska". W konkluzjach zwykle pojawiało się zdanie, że sympatie Polaków powinny się kierować: „...jedynie do tych narodów, które nie były katami Polski [a zaliczano do nich] w pierwszym rzędzie bohaterską Francję, a w drugim wyrachowaną, demokratyczną Anglię." 20 W ten sposób „Czas" ostrożnie, ale konsekwentnie budował wśród swych czytelników sympatie dla aliantów, po stronie których zaangażowana była Kanada. Nie dziwi więc, że już w numerze z pierwszego marca 1916 r. zamieszczono ogłoszenie: „Potrzeba rekrutów do służby za morzem. Mamy zamiar zapełnić jedną lub dwie kompanie wojska żołnierzami z Polaków, Rosjan i Rusinów. Przyjdźcie do nas ZARAZ. Będziemy potrzebować wszelkiego rodzaju rzemieślników. Wszelkich informacji udzieli Wam 184. Battalion, Biuro w Północnej stronie miasta, 986 Main Street"21. Ogłoszenie to (czasem z nagłówkiem Potrzeba Rekrutów) powtarzało się w kilku kolejnych numerach pisma.

Propaganda wojenna oraz nadzieje na szybkie zwycięstwo sprawiły, że w początkowym etapie wojny w Kanadzie nie brakowało ochotników do wojska. Struktura etniczna kontyngentu wysłanego do Europy na przełomie lat 1914-1915 znacząco różniła się jednak od mozaiki etnicznej społeczeństwa kanadyjskiego ${ }^{22}$. Ponad dwie trzecie żołnierzy i niższych oficerów Canadian Expeditionary Forces stanowili imigranci z Wysp Brytyjskich, osoby urodzone w Kanadzie jedynie 30\%, a francuskojęzyczni Kanadyjczycy niecałe $3 \%{ }^{23}$. Ci ostatni, rozproszeni po różnych oddziałach, nie zawsze dobrze rozumieli anglojęzycznych oficerów, a ich lojalność w stosunku do Imperium Brytyjskiego bywała kwestionowana. Władze i dowódcy wojskowi uważali też, że konflikt jest „wojną ludzi białych” (white man's war) i początkowo nie rekrutowano ani Afro-Kanadyjczyków, ani ochotników spośród Ludności Rodzimej. Oficjalnie motywowano to obawami o respektowanie jenieckiego statusu takich żołnierzy, gdyby

18100 lecie Towarzystwa Białego Orła i Polonii Montrealskiej, red. R. Rzepkowski, Montreal 2002, s 31.

19 Wojenna pożyczka Kanady, "Czas" 13.09.1916, s.4.

20 Orientacje, "Czas” 15.03.1916, s. 1.

21 "Czas" 1.03.1916, s. 6.

22 Według danych spisu powszechnego z 1911 r. 54\% Kanadyjczyków miało korzenie brytyjskie, 29\% stanowili frankofoni, a 22\% imigranci (wśród nich połowa z Wysp Brytyjskich). Zob. Conseil canadien pour les réfugiés / Canadian Council for Refugees, https://ccrweb.ca/en/hundred-years-immigrationcanada-1900-1999 (dostęp: 27.12.2019).

23 J.L. Granatstein, J.M. Hitsman, Broken Promisses. A History of Conscription in Canada, Toronto 1985, s. 23. 
dostali się do niewoli. Istnieją jednak dowody, że obawiano się głównie uprzedzeń rasowych własnych żołnierzy ${ }^{24}$.

Zmiany decyzji na temat rekrutacji ochotników z grup należących do widocznych mniejszości oraz przede wszystkim ze społeczności białych, nieanglojęzycznych imigrantów, następowały od roku 1916. Wpłynęły na to przedłużające się działania wojenne, spadek liczby ochotników, informacje o stratach na froncie oraz konieczność uzupełniania stanu oddziałów kanadyjskich. Znaczące okazało się również przywiązanie rządzących Kanadą konserwatystów do Imperium Brytyjskiego, złożone przez nich deklaracje stworzenia półmilionowej armii oraz ambicje kanadyjskich polityków do wykorzystania na arenie politycznej wkładu wojsk kanadyjskich w działania wojenne do umocnienia pozycji Dominium w Imperium Brytyjskim. Dzięki splotowi tych czynników do Canadian Expeditionary Forces zaczęto przyjmować przedstawicieli kanadyjskich grup etnicznych innych niż anglofoni i frankofoni. Mieszkający w Vancouver Japończycy na własny koszt przeprowadzili rekrutację i przy pomocy angielskich weteranów wyszkolili 227 ochotników pochodzenia japońskiego. Własny oddział stworzyli także żyjący w Kanadzie Duńczycy, a w Nowej Szkocji sformowano 600 osobowy batalion budowlany złożony z Afro-Kanadyjczyków. W ciągu czterech lat wojny w kanadyjskich oddziałach trafiło do Europy także około 3500 żołnierzy wywodzących się z różnych plemion indiańskich, kilka tysięcy Metysów, imigranci z wielu grup europejskich, a przed 1917 r. (zanim USA przystąpiły do wojny) także ochotnicy ze Stanów Zjednoczonych. Wśród tych ostatnich byli również Polacy. Relacje jednego z nich zamieszczał w lutym i marcu 1916 r., wydawany w Chicago, „Dziennik Związkowy". Autor tych publikacji, Aleksander M. Jasieński, pisał, że w formowanym Legionie Amerykańskim jest co najmniej kilkunastu Polaków z Detroit, Chicago i Cleveland. Podawał nawet nazwiska niektórych. Twierdził również, że co najmniej 300 Polaków jest w oddziałach kanadyjskich szkolonych przed wyjazdem do Europy i sugerował, że można by z nich stworzyć Legion Polski25.

Inicjatywa utworzenia polskiego oddziału przy wojsku kanadyjskim pojawiła się w Winnipeg już na początku 1916 r. W lutym w „Czasie” ukazała się krótka notatka, że Franciszek Szablowski udaje się na rozmowy w tej sprawie do Ottawy²6. Po miesiącu ta sama gazeta zaczęła publikować przytoczone wcześniej ogłoszenie o rekrutacji, a w połowie marca wydrukowała tekst, w którym opisano, że:

Po uchwaleniu na specjalnym zebraniu Polaków rezolucji utworzenia polskich pułków udano się do Ottawy z odpowiednią petycją i za pośrednictwem wpływowych delegatów projekt utworzenia polskich wojskowych oddziałów został w zasadzie przyjęty [i]

${ }^{24}$ D. Bell, White man's war': Military Museums exhibit takes honest look at ugly period, CBC News, February 07.2019, https://www.cbc.ca/news/canada/calgary/military-museum-exhibit-black-history-1.5008524 (dostęp: 27.12.2019).

${ }^{25}$ Czyn zbrojny wychodźstwa, ... red. J. Walter, s. 137-140.

26 Szablowski był inspektorem rolnym w Manitobie i działaczem Canadian Committee for the Polish 


\section{SM̂PP}

sprawa polskiego pułku stoi na najlepszej drodze [...]. O ile nam wiadomo sami Polacy [zaangażowani w tę inicjatywę] ofiarowali panu Hastings [chodziło prawdopodobnie o George'a Hastingsa Palmera (1881-1941)], byłemu prokuratorowi Manitoby, naczelne dowództwo tego pułku²7.

Wybór kanadyjskiego dowódcy tłumaczono chęcią uniknięcia wśród Polaków rywalizacji o to stanowisko. Zapowiadano jednak, że oficerami będą Polacy i wkrótce ogłoszone zostaną dalsze informacje. Pojawiły się one w "Czasie" dopiero w lipcu, ale były pełne entuzjazmu. Napisano tam: „Historyczną datą pozostanie dla Polaków dzień 7 lipca br., w tym bowiem dniu dominialny rząd Kanady uznał Polaków jako odrębną narodowość, nie mającą nic wspólnego z politycznymi zaborcami Polski [...] narodowość aspirującą do ojczyzny wolnej i niepodległej"28. W dalszej części tekstu podkreślano wagę pojawienia się sprawy polskiej i nazwy Polska oraz dumę z faktu, że: „... biednemu emigrantowi polskiemu w Kanadzie przypadł udział zorganizowania pierwszego polskiego pułku po stronie aliantów". Podkreślano też świadomość historycznego znaczenia jednostki, której organizację przygotowywano.

Informacje z "Czasu” przedrukował w Chicago "Dziennik Związkowy" i pod ich wpływem do Kanady wyruszyło dziesięciu Sokołów - ochotników z USA. Zostali oni jednak zatrzymani na granicy kanadyjskiej. Zaangażowany w akcję na terenie Kanady harcmistrz Andrzej Małkowski (twórca polskiego harcerstwa, weteran polskiego legionu walczącego po stronie Austrii przeciw Rosji, który w latach 1915-16 działał w Związku Sokołów w USA) twierdził, że przedwczesna wyprawa Sokołów była wynikiem intryg ambasady austriackiej. Niepowodzenie inicjatywy mającej na celu utworzenie polskiego legionu tłumaczył natomiast brakiem ostatecznej zgody Kanadyjczyków na jego „pełną narodową odrębność” oraz postawą krytyków, rozpowszechniających wśród polskich emigrantów pogłoski, że Kanadyjczycy chcą polski oddział wysłać do Rosji ${ }^{29}$. Historycy kanadyjscy, powołujący się na dokumenty z kancelarii premiera, twierdzą natomiast że w 1916 r. inicjatywa utworzenia polskiego batalionu została odrzucona, gdyż władze kanadyjskie obawiały się problemów językowych w oddziałach stworzonych z imigrantów, a także wzajemnych relacji między Rusinami, Niemcami, Polakami i Rosjanami. Negatywny wpływ miał też przypadek żołnierza pochodzenia duńskiego, walczącego w Korpusie Australijsko-Nowozelandzkim, który okazał się niemieckim szpiegiem ${ }^{30}$.

Po dwóch latach wojny, gdy zaczęło brakować ochotników do Kanadyjskich Sił Ekspedycyjnych, pojawiły się propozycje wprowadzenia obowiązkowego poboru rekrutów. Burzliwe dyskusje zakończyły się w lipcu 1917 r. przyjęciem w Ottawie The

27 Później okazało się, że inicjatorami zebrania i petycji była grupa aktywistów "Sokoła” z "Gniazda" 377 w Winnipeg. „Czas” 15.03.1916, s. 8.

28 "Czas" 12.03.1916, s. 4.

${ }^{29}$ Czyn zbrojny wychodźstwa, ... red. J. Walter s. 172.

30 J.L. Granatstein, J.M. Hitsman, Broken Promises. A History of Conscription in Canada, Toronto 1985, s. 48. 
Military Service Act, który wprowadzono w życie w styczniu 1918 r. Pobór wywołał gwałtowny opór: masowe uchylanie się od obowiązku służby wojskowej i wzrost napięć między kanadyjskimi anglofonami i frankofonami, gdyż ci ostatni zdecydowanie nie chcieli walczyć ani za Imperium Brytyjskie, ani za Francję. W kilku miastach Quebeku doszło do wystąpień ulicznych, a w kwietniu w Quebec City miały miejsce kilkudniowe zamieszki, w wyniku których 4 osoby zginęły, a kilkanaście odniosło rany ${ }^{31}$. W tej atmosferze, już pod koniec roku 1916, władze kanadyjskie bardziej życzliwie potraktowały zabiegi o utworzenie oddziału polskiego. Przedstawili je Andrzej Małkowski i Wincentego Skarżyński, działacze Związku Sokolstwa Polskiego w USA. W pełnej konspiracji przeprowadzono wśród Polonii amerykańskiej rekrutację 23 ochotników, którzy na początku stycznia 1917 r. rozpoczęli trzymiesięczny kurs podoficerski, zorganizowany w Canadian School of Infantry działającej przy University of Toronto. Brakuje niestety dokumentów umożliwiających rekonstrukcję okoliczności tej bezprecedensowej akcji oraz motywów strony kanadyjskiej. Spisane po latach relacje uczestników i organizatorów szkolenia zawierają niestety wiele niedomówień, a nawet rozbieżności.

W sprawozdaniu Franciszka Dzioba, który w okresie wojny był naczelnikiem Sokolstwa Polskiego w Ameryce, wyczytać można, że Małkowski i Skarżyński nawiązali kontakt z zamożnym kanadyjskim producentem papieru - Williamem Prince'em, który na własny koszt zamierzał zorganizować pułk wojsk kanadyjskich i zainteresował się przyjęciem rekrutów polskich z Kanady i USA. Związek Sokołów Polskich był gotów ich dostarczyć, ale postawił warunki. Wśród nich, na głównym miejscu, znalazło się uznanie przez rząd kanadyjski odrębności narodu polskiego. Władze Dominium Kanady nie mogły wydać takiej deklaracji, gdyż nie miały prawa do prowadzenia własnej polityki zagranicznej, a decyzje należące do tej sfery podejmował jedynie Londyn. Przekreśliło to dalsze negocjacje. Częściowo uratowała je jednak interwencja przeprowadzona w Ottawie przez Jana Horodyskiego, współpracującego zarówno z Paderewskim, jak i z Dmowskim. Kanadyjczycy wyrazili zgodę na przeszkolenie w Toronto 30 polskich Sokołów z USA na kursie podoficerskim, a Horodyski wyasygnował fundusze na wydatki związane z rekrutacją tej grupy. Sprawozdanie Dzioba przedstawiało Horodyskiego jako przybyłego ze Szwajcarii delegata Polaków i przypisywało mu główne zasługi w nawiązaniu kontaktów z wpływowymi Kanadyjczykami. Warto jednak dodać, że część polskich działaczy emigracyjnych uważała Horodyskiego za agenta brytyjskiego ${ }^{32}$.

Nieco inną wersję wydarzeń przedstawił, wspomniany wcześniej działacz Sokolstwa, Wincenty Skarżyński, który realizację idei szkolenia polskich kandydatów na podoficerów przypisał przypadkowi. W publikacji wydanej w 1929 r. niezwykle

${ }^{31}$ S. Durflinger, French Canada and Recruitment during the First World War, Canadian War Museum. Web. https://www.warmuseum.ca/learn/dispatches/french-canada-and-recruitment-during-the-first-worldwar/\#tabs (dostęp: 6.01.2020). 


\section{SM̂PP}

barwnie przedstawił swoją wersję wypadków: „Gdy przekraczałem granicę Kanady i Stanów Zjednoczonych w Windsor (Ontario), poznał mnie jeden z moich kolegów broni z armii amerykańskiej, któremu ongiś wyświadczyłem małą przysługę ułatwiając mu przejście do Meksyku w chwili, gdy znajdował się w poważnym niebezpieczeństwie"33. Okazało się, że był to syn przemysłowca Williama Prince'a, o którym wspominał naczelnik Sokolstwa. Prince senior chciał włączyć Skarżyńskiego do swego pułku, ale gdy wysłuchał opowieści o jego planach oraz setkach polskich ochotników w USA, ułatwił mu kontakt w Ottawie z odpowiedzialnym za rekrutację ministrem milicji - Samuelem Huges'em. Na to spotkanie, które miało się odbyć w obecności grona wojskowych, Skarżyński udał się razem z Małkowskim. Przedstawili propozycję wyszkolenia kadry i polskich ochotników do wojska, a także dezyderat, aby Kanada wyjednała zgodę Wielkiej Brytanii: „....na opowiedzenie się za niepodległością Polski w jej granicach historycznych z Gdańskiem i Królewcem"34. Skarżyński napisał, że dalszym etapem rozmów była konferencja „z udziałem oficerów angielskiego sztabu generalnego", która odbyła się później w Detroit, że wziął w niej udział Małkowski, a on sam zaangażował się w rekrutację ochotników na szkolenie w Kanadzie. Autor przytoczonej relacji wyraźnie minimalizował wpływ innych osób na decyzję Kanadyjczyków.

W pracy wydanej po ponad 20 latach od opisywanych wydarzeń Wacław Gąsiorowski powtórzył jednak wersję, że to Horodyski zdołał uzyskać zgodę Kanadyjczyków na uruchomienie kursu dla polskich podoficerów i że to on przekazał fundusze na organizację ich rekrutacjij ${ }^{35}$ Gąsiorowski wyraził jednak uznanie dla Skarżyńskiego i Małkowskiego jako inicjatorów działań w Kanadzie pisząc: „Dzisiaj uwierzyć trudno w te rozmowy i układy dygnitarzy kanadyjskich z dwoma młodzieńcami polskimi, którzy [...] reprezentowali własne szczere zapały do wojaczki, własną determinację szukania punktu oparcia w Kanadzie"36. Gąsiorowski potwierdził jednak fakt takich rozmów oraz spotkania delegacji alianckich wojskowych z działaczami Sokolstwa w Detroit. Jego zdaniem nie przyniosły one oczekiwanych rezultatów ze względu na kampanię oskarżeń o „zaprzedanie Rosji” rozpętaną przez Komitet Obrony Narodowej, reprezentujący w USA opcję proaustriacką. Według Gąsiorowskiego dopiero wizyta Horodyskiego u Generalnego Gubernatora Kanady umożliwiła przyjęcie grupy polskich Sokołów na kurs podoficerski w Toronto. Wszystkie przedstawione wersje wydarzeń wydają się splatać w całość. Potwierdzają istnienie wewnętrznych podziałów w społeczności polskiej w Ameryce oraz dokumentują emocje kierujące postaciami najbardziej zaangażowanymi w tworzenie polskiego wojska. Warto jeszcze zwrócić uwagę na odnotowane przez historyków zainteresowanie oraz życzliwość, jaką w stosunku do projektu tworzenia w Kanadzie polskiego oddziału wojskowego

\footnotetext{
33 Tamże, s. 189-190.

34 Tamże, s. 189.

35 W. Gąsiorowski, Historia Armii Polskiej, s. 228.

36 Tamże, s. 229.
} 
wykazał szef sztabu generalnego armii kanadyjskiej generał Willoughby Gwatkin, reprezentujący w Ottawie interesy Armii Brytyjskiej ${ }^{37}$.

Rekrutację ochotników na szkolenie przeprowadzono w głębokiej konspiracji. Pierwsza ich grupa, licząca 23 osoby, dotarła do Toronto już pod koniec grudnia 1916 r. i podjęła naukę w Canadian School of Infantry, funkcjonującej wówczas przy University of Toronto. Początkowo tam, a następnie w obozie wojskowym w Camp Borden, Kanadyjczycy przeszkolili do połowy 1917 r. jeszcze dwie grupy (łącznie 230 osób) polskich Sokołów - kandydatów na podoficerów ${ }^{38}$. Część z nich uczestniczyła wcześniej w kursach Szkoły Podchorążych działającej przy Kolegium Związku Narodowego Polskiego w Cambridge Springs w Pensylwanii od 19 marca 1917 r. Taką drogę przeszedł między innymi Witold Trawiński, uczestnik ostatniego kursu dla Polaków, rozpoczętego w Kanadzie w maju 1917 r. W jego wspomnieniach znaleźć można kilka ciekawych uwag na temat wojennej atmosfery panującej w Toronto. Trawińskiego zaskoczyła obecność wielu wojskowych na ulicach oraz fakt, że w czasie skromnej, powitalnej kolacji toast na cześć króla wzniesiono kieliszkami wypełnionymi wodą. Dopiero później skojarzył ten fakt z obowiązującą wówczas w Ontario prohibicją. Autor wspominał również, że pierwszy wykład dla przyszłych oficerów poświęcony został zachowaniu ścisłej tajemnicy, a uczestników kursu obowiązywał zakaz udzielania jakichkolwiek informacji prasie oraz podawania w listach szczegółów dotyczących pobieranej nauki, jej organizacji oraz nastrojów panujących wśród kolegów ${ }^{39}$.

Plany stworzenia polskiego batalionu przy armii kanadyjskiej uległy zmianie w obliczu wydarzeń z roku 1917. W lutym w Rosji wybuchła rewolucja, w kwietniu USA przystąpiły do wojny, a 4 czerwca prezydent Raymond Poincare podpisał dekret o tworzeniu Armii Polskiej we Francji. Władze USA były przeciwne powoływaniu etnicznych legionów w ramach własnej armii. W wyniku wielu, do dziś nie do końca znanych zabiegów polskich emigrantów, których wspierała dyplomacja brytyjska, prezydent USA Woodrow Wilson udzielił jednak zgody na rekrutację w Stanach Zjednoczonych ochotników do oddziałów polskich we Francji. Nie mogły to być osoby podlegające poborowi w USA, czyli obywatele amerykańscy między 19 a 23 rokiem życia. Ustalono też, że ich wstępne szkolenie zostanie sfinansowane przez Francję i przeprowadzone na terenie Kanady. W rezultacie tych decyzji, w kanadyjskiej miejscowości Niagara-on-the-Lake, położonej nad granicą z USA, od końca września 1917 r. zaczęto tworzyć, a w październiku uruchomiono obóz szkoleniowy dla polskich ochotników nazwany

37 Henry Radecki nazwał go nawet "ojcem chrzestnym Polskiej Armii”. Zob. H. Radecki, Polska ochotnicza Armia w Kanadzie, http://www.goniec.net/goniec/inne-dzialy/zycie-polonijne/polska-ochotnicza-armia-w-kanadzie-1917\%E2\%80\%931918.html (dostęp: 10.05.2016.); D. Morton, Gwatkin Sir Willoughby Garnons, Dictionary of Canadian Biography, vol. XV, http://www.biographi.ca/en/bio/gwatkin_willoughby_garnons_15E.html (dostęp: 19.01.2020).

${ }_{38}$ R.D. Merritt, Training for Armageddon. Niagara Camp in the Great War, 1914-1919, Victoria BC 2015, s. 161.

39 W.H. Trawiński, Odyseja Polskiej Armii Błękitnej, Wrocław 1989, s. 91, 103-104. 


\section{SM̂PP}

Obozem Kościuszko. Kanadyjczycy odpowiadali za jego organizację, a w praktyce kredytowali też jego wyposażenie i zaopatrzenie oraz umundurowanie ochotników ${ }^{40}$.

Komendantem polskiego obozu został mianowany Arthur D'Orr LePan, dwudziestotrzyletni pułkownik z wykształceniem inżynierskim. Łączył on pochodzenie irlandzkie oraz francuskie i już wcześniej odpowiadał za szkolenie polskich podoficerów na kursach w Toronto i Camp Borden. Po latach wspominat, że do nowego, wyznaczonego mu przez dowództwo zadania, podszedł z wieloma obawami ${ }^{41}$. W opinii H. Trawińskiego LePan „był typem chodzącego rygoru i powagi”, ale cieszył się poważaniem zarówno wśród oficerów, jak i wśród żołnierzy. Mimo zachowywanego dystansu bardzo troszczył się o swych polskich podkomendnych. Doceniał też ich entuzjazm, dyscyplinę, wytrwałość i zaangażowanie w trakcie ćwiczeń, czynione postępy oraz poświęcenie na rzecz własnej ojczyzny ${ }^{42}$. Poza pułkownikiem LePan'em w kadrze obozu znalazło się jeszcze 28 kanadyjskich oficerów, wśród nich weteran wojen burskich - kapitan Henry E. Pembroke i cieszący się dużą popularnością wśród polskich rekrutów - Alexander George E. Smith, uczestnik bitwy nad Sommą, Indianin z irokeskiego plemienia Cayuga ${ }^{43}$. Do tej kadry dołączyło 180 nowo wyszkolonych polskich oficerów i podoficerów. Dotarli oni do Niagara-on-the-Lake 28 września 1917 r. W ciągu kilku dni przygotowano obozową infrastrukturę i rozbijano ośmioosobowe, płócienne namioty. Trzeciego października do obozu przybyła pierwsza grupa polskich ochotników z Buffalo. W ciągu następnych dni przyjeżdżali kolejni, czasem nawet po trzystu dziennie ${ }^{44}$.

$\mathrm{Na}$ terenie USA działały 43 ośrodki rekrutacyjne, a w Kanadzie cztery: w Winnipeg, Toronto, Montrealu i w miejscowości Wilno w prowincji Ontario. W Wilnie i w jego okolicy od połowy XIX w. istniało kilka osiedli kaszubskich. Lokalny proboszcz ks. Bronisław Jankowski bardzo zaangażował się w rekrutację i dzięki niemu z tego niewielkiego skupiska zgłosiło się aż 22 spośród 221 ochotników z terenu Kanady, a do Niagara-on-the-Lake przesłano paczkę zawierającą bieliznę, skarpety, swetry i rękawice wykonane przez parafianki księdza Jankowskiego ${ }^{45}$. Do obozu Kościuszko zgłaszali się jednak głównie ochotnicy z USA, w większości Sokoli. Najwyższy stan liczebny (4 279 osób) odnotowano pod koniec listopada 1917 r. - 62\% wszystkich

40 R.D. Merritt, Training for Armageddon, s. 162-163; Raport pułkownika LePan, 26.031919 r., w: Czyn zbrojny wychodźstwa, ... red. J. Walter, s. 459-465.

${ }^{41}$ S. Skrzeszewski, The Daily Life of Polish Solders Niagara Camp, 1917-1919. The Newspaper Columns of Elizabeth Ascher St. Catherines Standard, 1917-1919, http://www.nhsm.ca/media/Standard19171919Draft2-StanSkrzeszewski.pdf (dostęp: 19.01.2020).

42 W.H. Trawiński, Odyseja Polskiej Armii, s. 120.

${ }^{43}$ R.D. Merritt, Training for Armageddon, s. 173-174.

${ }_{44}$ M.B. Biskupski, Canada and the Creation of a Polish Army, 1914-1918, "The Polish Review", vol. XLIV, no. 3 (1990), s. 377; H. Radecki, Polska Ochotnicza Armia w Kanadzie 1917-1918, http://www.goniec.net/goniec/inne-dzialy/zycie-polonijne/polska-ochotnicza-armia-w-kanadzie-1917\%E2\%80\%931918. html (dostęp: 9.01.2020.)

${ }^{45}$ S.M. Connolly, Local Polish Soldier Remembered in Museum Exhibit at Niagara-on-the-Lake, News from the Wilno Heritage Museum and Polish Kashub Heritage Museum, Fall/Winter 2017, t. 16 nr. 2, s. 17. 
ochotników podawało się za "rosyjskich Polaków”, 31,5\% za „austriackich Polaków”, a 3\% za „niemieckich Polaków; inni stanowili 3,5\%46. Przyjmowano także ochotniczki. 40 młodych kobiet, po przeszkoleniu pielęgniarskim, pracowało jako sanitariuszki w obozowym szpitalu polowym. Większość z nich wyjechała z polskimi oddziałami do Francji. Pierwszy polski transport wyekspediowano już w grudniu 1917 r. ${ }^{47}$ Łącznie przez 18 miesięcy w obozie w Niagara-on-the-Lake trening przeszło 22395 Polaków, a 20720 z nich, partiami, wysłano do Francji" ${ }^{48}$.

W trakcie szkolenia rekruci byli w znacznym stopniu angażowani w prace związane z organizacją, a następnie z funkcjonowaniem obozu. Odbywali także codziennie kilkugodzinną musztrę i długie marsze. Program ćwiczeń obejmował sztuki walki, posługiwanie się bronią oraz bagnetami, a także używanie broni ciężkiej i granatów. Te ostanie umiejętności miały być doskonalone już we Francji. W obozie wprowadzono regulamin francuski, ale komendy wydawano po angielsku, francusku i po polsku. Kanadyjscy instruktorzy musieli się więc nauczyć podstawowych polskich zwrotów, kilku słów umożliwiających komunikację z podkomendnymi, ale też wymowy trudnych polskich nazwisk. Żołd wypłacano według stawek francuskich (ochotnicy po 5 centów dziennie, a oficerowie 1,12 \$). Każdy polski ochotnik miał też prawo do premii w wysokości 150 \$ rocznie ${ }^{49}$. Część żołnierzy nosiła kanadyjskie mundury w kolorze khaki. Kiedy ich zabrakło, wykorzystywano zapasy mundurów (głównie czerwonych, ale też niebieskich i białych) kanadyjskiej milicji i wojsk wewnętrznych. Ochotników polskich wyróżniały czapki rogatywki z polskim orzełkiem. W obozie oraz na defiladach organizowanych poza nim, oddziały występowały z polskimi sztandarami wykonanymi przez członkinie polonijnych organizacji w USA ${ }^{50}$.

Już w pierwszych dniach funkcjonowania obozu rozpoczęto budowę czterech dużych piętrowych baraków, z których każdy mógł pomieścić 300 osób. Przed nadejściem mrozów udało się ukończyć jedynie trzy i część ochotników, mimo bardzo niskich temperatur, musiała nocować w namiotach. Jeden z nowo sformowanych oddziałów został w zimie przeniesiony do St. Johns, Que. (obecnie Saint-Jean-sur Richelieu), a inny tymczasowo do starego Fortu Niagara po amerykańskiej stronie granicy. W okresie największych mrozów około 2 tys. polskich ochotników znalazło czasowe schronienie w miasteczku położonym w pobliżu obozu. Jego mieszkańcy,

${ }^{46}$ Czyn zbrojny wychodźstwa, ... red. J. Walter, s. 460.

47 Miał odpłynąć z Halifaxu, ale plany podróży skomplikowało tragiczne zderzenie w porcie dwóch statków, z których jeden był wyładowany amunicją; zginęło 2 tys. osób, a port i część miasta uległy zniszczeniu. Zob.: Halifax Explosion w: The Canadian Encyclopaedia, https://www.thecanadianencyclopedia.ca/en/ article/halifax-explosion (dostęp: 15.01.2020). Ciekawe, że w relacjach polskich ochotników eksplozja została przypisana działaniom niemieckich szpiegów. Zob.: Czyn zbrojny wychodźstwa, ... red. J. Walter, s. 467.

48 R.D. Merritt, On the Common Ground: The Ongoing Story of the Commons in Niagra-on-the-Lake, Toronto 2012, s. 141; M.B. Biskupski, Canada and the Creation, s. 377.

49 R.D. Merritt, On the Common Ground, s. 136.

50 Training for Armageddon, s. 183. Warto odnotować, że na kilku zachowanych fotografiach nie- 


\section{SM̂PP}

na apel komendanta, udostępnili rekrutom (w większości bezpłatnie) nie tylko wolne miejsca hotelowe i letnie domy, ale także stodoły, garaże, puste magazyny po fabryce puszek, budynek straży pożarnej, a nawet łaźnię i ratusz ${ }^{51}$. Wszystko to dowodziło otwartości i życzliwości ze strony lokalnej ludności.

Niagara-on-the-Lake była niewielkim, prowincjonalnym kanadyjskim miasteczkiem o charakterze letniskowym. Na jego obrzeżach już od 1812 r. okresowo organizowano obozy szkoleniowe armii kanadyjskiej. Były to jednak wyłącznie obozy letnie i nigdy nie miały tak wielkich rozmiarów jak obóz polski. Mieszkańcy Niagara-on-the-Lake byli więc początkowo sceptycznie nastawieni do "inwazji cudzoziemców", a niektórzy nawet się ich obawiali. Uprzedzenia szybko jednak zostały przełamane. Miasto czerpało znaczne zyski z zaopatrzenia obozu. Ożywiły się też miejscowe małe przedsiębiorstwa, warsztaty, restauracje, cukiernie. Oficerowie wynajmowali letniskowe domy w okolicy, komplety gości miały trzy lokalne hotele (jeden z nich zmienił nawet nazwę z The Lake View Hotel na Hotel Kościuszko). W Niagara-on-the-Lake oraz w pobliskim St. Catherines organizowano bale dla oficerów i spotkania przy herbacie. Dla zapewnienia żołnierzom rozrywki YMCA uruchomiła bibliotekę (z książkami w językach angielskim i francuskim, ale też polskim), salę gimnastyczną i kino, w którym wyświetlano nieme filmy oraz materiały propagandowe. W budynku teatru, w parku, a nawet w lokalnej hali masońskiej organizowano dla żołnierzy koncerty i popisy wokalne oraz występy wodewilowe. Większość z tych atrakcji była dostępna także dla mieszkańców Niagara-on-the-Lake. W obozie polskim utworzono natomiast trzy zespoły muzyczne, które brały udział w organizowanych w mieście zabawach, paradach i uroczystościach religijnych (także protestanckich).

Ogromnym zainteresowaniem wśród Kanadyjczyków cieszyły się też wizyty składane w Niagara-on-the-Lake przez Polaków i Amerykanów o znanych nazwiskach. Byli wśród nich między innymi: Richard Ordynski (dyrektor sceniczny Metropolitan Opera w Nowym Jorku), pisarz Wacław Gąsiorowski, malarz Sigismund de Ivanowski, Laura Gozdawa Turczynowicz (kanadyjska śpiewaczka zaangażowana w polską akcję rekrutacyjną, żona polskiego arystokraty, która początek wojny spędziła w Galicji), Alfred Korzybski (inżynier, matematyk i filozof) oraz jego żona - Mira Edgerly (amerykańska malarka miniatur portretowych). Do Niagara-on-the-Lake kilkakrotnie przyjeżdżał również sam Ignacy Paderewski. Pobyt każdej z tych osób był dla mieszkańców miasteczka niezwykłym wydarzeniem. Informowano o tym w lokalnym dzienniku "St. Catherines Standard", wychodzącym w sąsiednim mieście. W piśmie tym stałą kolumnę prowadziła, mieszkająca w Niagara-on-the-Lake, Elizabeth Ascher. Publikowała wiele wiadomości na temat polskiego obozu, jego osiągnięć i problemów oraz ważnych wydarzeń, które miały tam miejsce. Nie zajmowała się działalnością polityczną. Opisywała natomiast życie codzienne w mieście, a także w polskim obozie. W swej rubryce zamieszczała też krótkie, przystępne informacje o Polakach i o ich wysiłkach na rzecz 
odbudowy niepodległości własnej ojczyzny. Autorka udzielała również współmieszkańcom rad dotyczących polskich zwyczajów i zachowania w stosunku do polskich żołnierzy. Poza pracą dziennikarską angażowała się także w różnego rodzaju przedsięwzięcia i zbiórki na rzecz Obozu Kościuszko. Po jego likwidacji uczestniczyła w akcji wysyłania polskim żołnierzom paczek do Europy oraz w zbiórkach obuwia i ubrań dla Iudności cywilnej na ziemiach polskich, które prowadził Polski Biały Krzyż kierowany przez Helenę Paderewską 52 .

Władze obozu musiały też stawić czoło wielu problemom różnej wagi. Jesienią 1917 r., gdy zaczęły się deszcze i pojawiło się błoto, okazało się, że polscy ochotnicy nie mają odpowiedniego obuwia. Zbliżająca się zima zapowiadała dalsze komplikacje, a Francuzi nie chcieli finansować butów. Atmosferę grożącą buntem rozładowała decyzja komendanta o wydaniu odpowiedniego obuwia z magazynów kanadyjskich $^{53}$. Znacznie poważniejsze były natomiast skutki dwóch fal epidemii grypy hiszpanki, które jesienią 1918 r. oraz wiosną 1919r. przeszły przez obóz. Zachorowało kilkuset ochotników, 31 z nich oraz dwóch kanadyjskich instruktorów zmarło. Dwadzieścia polskich ofiar grypy pochowano na katolickim cmentarzu lokalnej parafii St. Vincent de Paul54.

W kilku relacjach prasowych pojawiały się dwuznaczne wzmianki o odwiedzających ochotników „dziewczętach z Bostonu”. Brakuje jednak dowodów świadczących o tym, że wizytom tym przeciwdziałali pilnujący dyscypliny oficerowie lub któryś z 19 obozowych kapelanów przybyłych z USA. Zdecydowana większość polskich rekrutów deklarowała głębokie przywiązanie do Kościoła katolickiego. Regularnie uczestniczyli oni też w mszach i ceremoniach religijnych. Księża wspierali obóz polski także w inny, niekonwencjonalny sposób. Sześciu z nich, na plebanii polskiej parafii w pobliskim mieście St. Catherines, za zgodą władz kanadyjskich, uruchomiło biuro wydające polskie paszporty z kanadyjskimi wizami. Dokumenty te legalizowały pobyt w Kanadzie. Wydawano je osobom, które w tym kraju uznawane były za wrogów, bo nie miały obywatelstwa amerykańskiego, a pochodziły z toczących wojnę z aliantami Niemiec i Austrii. Brakuje materiałów opisujących, w jaki sposób tacy ochotnicy docierali do St. Catherines, jak duchowni stwierdzali, że zgłaszający się rzeczywiście są Polakami oraz czy i ile ochotnicy musieli zapłacić za takie polskie paszporty. Henry Radecki twierdzi, że w St. Catherines wydano ich $443^{55}$. Cała akcja świadczy o ogromnym zaufaniu władz kanadyjskich do wspomnianej grupy polskich księży, a na podkreślenie zasługuje dodatkowo fakt, że wydawane przez nich dokumenty były najprawdopodobniej

52 Elizabeth Ascher była też jedną z inicjatorek opieki nad kilkudziesięcioma grobami polskich ochotników, którzy zmarli w Niagara-on-the-Lake na skutek zapalenia płuc oraz w wyniku epidemii grypy hiszpanki. Po wojnie, za swoje zaangażowanie, została przez władze polskie odznaczona krzyżem Polonia Restituta; zob.: R. Baraniecki, Elizabeth Caroline Ascher, w: Niagara on the Lake Public Library, Niagara-on-the-Lake Heritage Portal, http://vitacollections.ca/notlheritage/2784339/data (dostęp: 11.01.2020).

${ }^{53}$ W.H. Trawiński, Odyseja Polskiej Armii, s. 144-151.

${ }^{54}$ R.D. Merritt, On the Common Ground, s. 142.

${ }^{55}$ H. Radecki, Polska ochotnicza Armia w Kanadzie, (dostęp: 10.05.2016). 


\section{SM̂PP}

pierwszymi paszportami polskimi. Powyższy przykład pokazuje, że akcje związane z funkcjonowaniem polskiego obozu znacznie wykraczały poza Niagara-on-the-Lake.

Zupełnie inny wymiar miało zetknięcie się polskich ochotników z francuskojęzyczną ludnością Kanady. Dotyczyło to 2400 polskich rekrutów, który pod koniec listopada 1917 r. wysłani zostali do wspomnianego wcześniej St. Johns w Quebecu. Znalazł się tam między innymi Witold Trawiński, który w swoich wspomnieniach opisał zarówno podróż, jak i nowe koszary, zorganizowane w dawnej fabryce octu. Podkreślił, że w budynku było ciepło, ale na zewnątrz nieustannie panował siarczysty mróz i przybywało śniegu oraz zasp. Autor żartobliwie nazwał cały rejon „kanadyjską lodówką". Zarejestrował, że mieszkańcy (poza kilkunastoma rodzinami) mówili wyłącznie po francusku i że początkowo patrzyli na Polaków podejrzliwie. Przytoczył też krążącą po mieście plotkę, według której polscy ochotnicy zostali sprowadzeni przez Anglosasów "przeciwko Frankofonom [...] jako oponentom obrony Francji, która rozeszła się z Kościołem"56. Trawiński tłumaczył to faktem, że Francuzi z Quebecu, będący zagorzałymi katolikami, bojkotowali ochotniczy zaciąg do wojska kanadyjskiego i oponowali przeciw planom przymusowego poboru. Relacje mieszkańców St. Johns z Polakami zdecydowanie się poprawiły, "gdy ci, budując ściany ze śniegu, skutecznie włączyli się w akcję gaszenia lokalnego pożaru"57.

Brak miejsca w obozie w Niagara-on-the-Lake, brytyjskie priorytety w przewozach przez Atlantyk i zaniedbania po stronie USA, wpłynęły pod koniec 1917 r. na ograniczenie rekrutacji polskich ochotników i opóźnienie ich wyjazdu do Europy ${ }^{58}$. Wywołało to dezorientację i frustrację w polskich oddziałach. Sytuacja uległa poprawie dopiero w 1918 r., w dużym stopniu dzięki naciskom kanadyjskich dyplomatów i wojskowych oraz niezwykłemu zaangażowaniu pułkownika LePan'a. Większość przeszkolonych polskich rekrutów odpłynęła do Francji do maja 1918 roku, ale obóz, wygaszając swoją działalność, funkcjonował jeszcze do lutego 1919 r. ${ }^{59}$ Po wojnie pułkownik Arthur LePan oraz dziennikarka Elisabeth Ascher otrzymali najwyższe polskie odznaczenia wojskowe - Krzyże Komandorskie Orderu Polonia Restituta. LePan, a także major Young, jeden z jego współpracowników z okresu funkcjonowania obozu w Niagara-on-the-Lake, próbowali jeszcze pomagać Polakom w roku 1941, kiedy ponownie, w zupełnie innych warunkach, pojawił się pomysł rekrutacji w Ameryce polskich ochotników. Ówczesna akcja werbunkowa przyniosła jednak niewielkie efekty ${ }^{60}$.

W Niagara-on-the-Lake wspominano Polaków jako wyjątkowo spokojnych i zdyscyplinowanych żołnierzy. Także obecnie dzieje polskiego obozu cieszą się tam zainteresowaniem członków lokalnego towarzystwa historycznego oraz związanego z nim

56 W. Trawiński, Odyseja Polskiej Armii, s.161.

57 Tamże.

58 M. Biskupski, Canada and the Creation, s. 372

59 Tamże, s. 377-380.

60 Zgłosiło się jedynie 1250 rekrutów i tylko 903 osoby wysłano do Europy. Zob.: A. Reczyńska, Piętno wojny. Polonia kanadyjska wobec polskich problemów lat 1939-1945, Kraków 1997, s. 98-107. 
muzeum, które gromadzi i eksponuje polskie pamiątki z okresu I wojny światowej. Polski cmentarz przy kościele St. Vincent de Paul, gdzie pochowano ofiary grypy hiszpanki oraz kilka osób związanych z polskim obozem, zmarłych już po wojnie (między innymi jednego z byłych kapelanów ks. Jana Józefa Dekowskiego), jest do dziś miejscem corocznych uroczystości patriotycznych, organizowanych przez działające na emigracji stowarzyszenia polskich weteranów oraz organizacje polonijne z Kanady i USA. Odwiedzają go też polscy politycy składający wizyty w Kanadzie. Wszystkie te fakty potwierdzają, że wojenna historia miejscowości Niagara-on-the-Lake sprzed ponad 100 lat, stanowi ciekawy i niezwykle ważny wycinek dziejów relacji polsko-kanadyjskich. Dodatkowo warto podkreślić, że odnosi się to do okresu, kiedy Kanada nie funkcjonowała jeszcze na arenie międzynarodowej, a Polska nie istniała na mapie świata.

\section{Bibliografia}

100 lecie Towarzystwa Białego Orła i Polonii Montrealskiej, red. R. Rzepkowski, Montreal 2002. Auleytner J., Komunikacja pocztowa w Błękitnej Armii Hallera w latach 1917-1920, Warszawa 2017. Baraniecki R., Elizabeth Caroline Ascher, w: Niagara on the Lake Public Library, Niagara-on-the Lake Heritage Portal, http://vitacollections.ca/notlheritage/2784339/data.

Bell D., White man's war': Military Museums exhibit takes honest look at ugly period, CBC News, February 07.2019, https://www.cbc.ca/news/canada/calgary/military-museum-exhibit-black-history-1.5008524 (dostęp: 27.12.2019)

Biskupski M.B., Canada and the Creation of a Polish Army, 1914-1918, "The Polish Review", vol. XLIV, no. 3 (1990), s. 339-380.

Bumsted J.M., The Peoples of Canada. A Post-Confederation History, Oxford-New York 2004, s. $190-201$.

Connolly S.M., Local Polish Soldier Remembered, w: Museum Exhibit at Niagara-on-the-Lake, News from the Wilno Heritage Museum and Polish Kashub Heritage Museum, Fall/Winter 2017, t. 16, nr 2, s. 15-18.

Conseil canadien pour les réfugiés / Canadian Council for Refugees https://ccrweb.ca/en/hundred-years-immigration-canada-1900-1999 (dostęp: 27.12.2019).

Czyn zbrojny wychodstwa polskiego w Ameryce. Zbiór dokumentów i materiałów historycznych, New York-Chicago 1957.

Czyn zbrojny wychodźstwa Polskiego w Ameryce 1914-1920. Zbiór dokumentów i materiałów historycznych, red. J. Walter, New York-Opole 2018.

Durflinger S., French Canada and Recruitment during the First World War, Canadian War Museum, http://www.warmuseum.ca/learn/dispatches/french-canada-and-recruitment-uring-the-firstworld-war/\#tabs (dostęp: 6.01.2020).

Dauglas Francis R., Jones R., Smith D.B., Journeys: A History of Canada, Toronto: Tomson/Nelson 2006 , s. $148-166$.

Dwa razy daje ten, kto zaraz daje, „Czas” 16.08.1916, s. 4.

Durflinger S., French Canada and Recruitment during the First World War, Canadian War Museum. Web. https://www.warmuseum.ca/learn/dispatches/french-canada-and-recruitment-duringthe-first-world-war/\#tabs (dostęp: 6.01.2020).

244 Gąsiorowski W., Historia Armii Polskiej we Francji 1915-1916, Łódź 1939. 


\section{SM̂PP}

Generał Józef Haller i jego żołnierze. Informator wystawy Muzeum Niepodległości, red. T. Skoczek, Warszawa-Wrocław 2018.

Granatstein J.L., Hitsman J.M., Broken Promises. A History of Conscription in Canada, Toronto 1985.

Halifax Explosion, w: The Canadian Encyclopaedia, https://www.thecanadianencyclopedia.ca/en/ article/halifax-explosion (dostęp: 19.01.2020).

Hryniuk S., Pionier Bishop, Pionier Times: Nikita Budka in Canada, w: Prophets, Priests, and Prodigals. Readings in Canadian Religious History, 1608 to the Present, ed. M.G. McGowan, D.B. Marchal, Toronto 1992.

Internment, w: Historica Canada, http://www.thecanadianencyclopedia.ca/en/article/internment (dostęp 5.01.2020)

Internowani Polacy w Kanadzie wypuszczeni na wolność, „Czas” 30.08.1916, s. 2.

Maksymowicz A., Agnieszka Wisła i działalność Polek w Ameryce na rzecz ochotników weteranów Błękitnej Armii, Nowy Jork-Opole 2015.

Maksymowicz A., W drodze do niepodległości. Kanadyjski przystanek Obóz Kościuszko w Niagara-on-the Lake (1917-1919), Zielona Góra 2017.

Merritt R.D., On the Common Ground: The Ongoing Story of the Commons in Niagra-on-the-Lake, Toronto 2012.

Merritt R.D., Training for Armageddon. Niagara Camp in the Great War, 1914-1919, Victoria BC 2015. Morton D., Gwatkin Sir Willoughby Garnons, Dictionary of Canadian Biography, vol. XV (1920-1930), http://199.167.129.205/en/bio/gwatkin_willoughby_garnons_15E.html (dostęp: 19.01.2020)

Odezwa Polaków do Rządu kanadyjskiego w sprawie zatwierdzenia prawego stanowiska Polaków do Dominium, "Gazeta Katolicka” 23.06.1914, s. 1.

Orientacje, „Czas” 15.03.1916, s. 1.

Radecki H., Polska ochotnicza Armia w Kanadzie, http://www.goniec.net/goniec/inne-dzialy/zycie-polonijne/polska-ochotnicza-armia-w-kanadzie-1917\%E2\%80\%931918.html (dostęp: 10.05.2016).

Radziwiłowicz D., Błękitna Armia w 80. rocznicę utworzenia, Warszawa 1997.

Reczyńska A., Emigracja z Polski do Kanady w okresie międzywojennym, Wrocław 1986.

Reczyńska A., Piętno wojny, Polonia kanadyjska wobec polskich problemów lat 1939-1945, Kraków 1997.

Samulski J., Pamiętnik emigranta polskiego w Kanadzie, red. B. Szydłowska-Ceglowa, Wrocław 1978. Shykula M., Korchinski B., Pionier Bishop: The Story of Bishop Nicetas Budka's Fifteen Years in Canada, Regina 1991.

Skrzeszewski S., The Daily Life of Polish Solders Niagara Camp, 1917-1919. The Newspaper Columns of Elizabeth Ascher St. Catherines Standard, 1917-1919, http://www.nhsm.ca/media/ Standard1917-1919Draft2-StanSkrzeszewski.pdf (dostęp: 19.01.2020).

The Canadian Great War Soldier, w: Historica Canadiana. http://www.thecanadianencyclopedia. ca/en/article/the-canadian-great-war-soldier/.

Trawiński W.H., Odyseja Polskiej Armii Błękitnej, Wrocław 1989.

Walker J.W.St.G., Race and Recruitment in World War I: Enlistment of Visible Minorities in the Canadian Expeditionary Force, w: Reappraisals in Canadian History. Post Confederation, red.

R.M. Bray, C.M. Wallace, Scarborough, Ont. 1999, s. 258-281.

Wojenna pożyczka Kanady, "Czas” 13.09.1916, s. 4.

Wojna, „Gazeta Katolicka”, 12.08.1914, s. 4. 